\title{
Convergence in tourism management research: a bibliometric analysis
}

\author{
Convergência na investigação da gestão do turismo: uma análise bibliométrica
}

\author{
Cristina Estevão \\ Escola Superior de Gestão de Idanha-a-Nova - Instituto Politécnico de Castelo Branco, Portugal \\ Núcleo de Estudos em Ciências Empresariais \\ cristina.estevao@ipcb.pt \\ Ana Rita Garcia \\ Escola Superior de Gestão de Idanha-a-Nova - Instituto Politécnico de Castelo Branco, Portugal \\ anarita@ipcb.pt \\ Sara Brito Filipe \\ Escola Superior de Gestão de Idanha-a-Nova - Instituto Politécnico de Castelo Branco, Portugal \\ sarafilipe@ipcb.pt \\ Cristina Fernandes \\ Escola Superior de Gestão de Idanha-a-Nova - Instituto Politécnico de Castelo Branco, Portugal \\ NECE - Núcleo de Estudos em Ciências Empresariais \\ cristina.fernandes@ipcb.pt
}

\begin{abstract}
The tourism sector has correspondingly attracted a great deal of interest from many researchers with particular focuses falling on tourism management and witnessing exponential growth in the research on this field. Given this, the objective of this current study involves producing a chart of these scientific publications, identifying their intellectual structure and the research trends in tourism management. Our research thus seeks to contribute towards: (i) mapping the intellectual structure of research on tourism management as depicted in the academic literature, (ii) identifying the fundamental contributions made by the tourism management research field, (iii) determining the lines of research constituting its intellectual structure, (iv) identifying the scientific journals with the greatest impact on this area and (v) identifying the geographic distribution of knowledge, by universities and countries, and the collaborative structures.
\end{abstract}

Keywords: Tourism management, marketing, governance, destination management, sustainability, bibliometric analysis.

\section{Resumo}

O turismo tem-se destacado pelo potencial de expansão à escala mundial, desempenhando um papel relevante como ferramenta de competitividade e motor de desenvolvimento regional. Esta temática tem sido alvo de grande interesse por parte de muitos investigadores, com especial incidência na gestão do turismo, verificando-se um crescimento exponencial de investigação nesta área. Face ao exposto, o objetivo do presente estudo é realizar um mapeamento das publicações científicas, estrutura intelectual e tendências de investigação relacionadas com a gestão do turismo. Neste contexto a nossa pesquisa pretende contribuir para o avanço da literatura. Para tal, efetuámos uma análise bibliométrica ao conceito "tourism management" procurando conhecer a investigação realizada.

Palavras-chave: Gestão do turismo, marketing, governação, gestão do destino, sustentabilidade, análise bibliométrica.
1. Introduction

Tourism gets ranked as one of the most important sectors worldwide with the literature testifying to a large consensus about its key role in the progress and competitiveness of many regions (Lazzeretti, Boix, \& Capone, 2008; Alberti \& Giusti, 2012). Clearly, this activity may also cause negative impacts on the respective tourism destinations such as the deterioration of the surrounding environment and the deformation of local cultural patterns (Cabezas, 2008). Based upon these premises, Alberton, Barddal and Campos (2009) highlight the need to evaluate and plan its utilisation, taking into consideration the drawbacks and disadvantages that may stem from poorly supervised and managed tourism activities. Therefore, being able to establish, nurture, protect and strengthen tourist destinations and their respective positionings in increasingly competitive and global markets constitutes a major challenge to the tourism industry (Crouch, 2007). According to Sainaghi (2006), the organisations managing destinations play a crucial role, alongside local companies, whether in establishing sustainable competitive advantages or in fostering these competitive advantages through their respective choices over positioning.

We thus consider that the "tourism management" research field proves relatively fragmented. In fact, there is no systematic review of the literature and its current state-ofthe-art remains unknown. What are the main contributions emerging from this field of study? Hence, this represents the context to which our research aims to contribute towards advancing the literature through carrying out bibliometric analysis of the "tourism management" concept seeking to better grasp the research already undertaken (Mutschke, Mayr, Schaer, \& Sure, 2011).

The methodology applied to ascertain the evaluation of the research performance draws upon the utilisation of quantitative and statistical analysis of scientific articles and their respective citations based upon ISI Web of Science data 
and articles published by journals in the categories of management, business and economics. The collection of scientific articles on a specific domain enables the understanding of the activities and impacts of the research, especially among researchers, by journal, country and university (Hawkins, 1977; Osareh, 1996; Thomsom Reuters, 2008). This study correspondingly employs a combination of bibliometric techniques such as citations, co-citations and analysis of the social networks portraying the scientific domain for tourism management. We therefore propose to provide researchers interested in the tourism management field with a map of the publications interrelated with this area as well as evaluating their state of evolution.

We begin by setting out the theoretical framework of research approaching tourism and tourism management before then describing the methodology applied, the data resulting and then finally detailing the results and their respective conclusions.

\section{Theoretical Framework}

\subsection{Tourism and Tourism Management}

The tourism sector has proven one of the sectors of activity with the greatest potential worldwide. This growth potential comes in association with a product that may only be consumed at the location, a characteristic that renders the sector an integral facet to any local development strategy. Furthermore, throughout many years, governments and the population in general ignored its economic and social importance with this recognition only recently awarded (Crouch \& Ritchie, 1999). In truth, the sector has long since been an authentic source of creating both value and jobs (Botti, Camprubi \& Torrès, 2008), an extremely important economic activity playing a decisive role in the development of some regions where, sometimes, there are no other available alternatives whilst also leveraging the dynamism of the natural and historical-cultural potential of lesser developed regions (Cabugueira, 2005).

The tourism sector also comprises of activities characterised by their enormous scope for producing direct, indirect and induced effects on an economy, whether through employment or through the dynamics of other companies already operating there (Carvalho \& Vaz, 2005). Campos, Mendes and Albino (2006) point out how this sector of activity is rising in both scale and value to national and regional economies, which develop through both the provision of services associated with the needs, expectations, demands and desires of tourist clients and the activities ongoing at the respective destination. According to Jackson and Murphy (2002), governments themselves identify tourism as a possible means for attaining economic development due to the scarcity of employment in the traditional economic sectors. In the opinion of Cabugueira (2005), the majority of activities and services constituting any tourism product tend to interlink with any natural or cultural attraction. The natural and cultural assets thus become directly productive and participating in the general process of economic expansion. Rodrigues (2003) states that while in other economic activities the products travel to the marketplace, in tourism precisely the opposite takes place. For the effective consumption of tourism products, tourists have to travel to the structure providing the product: the tourism destination. The author furthermore affirms that it is not possible to detach any approach to tourism products from their respective destination with this facet representing a central factor to tourism activities. This couples with the capacity of its economic activities to produce multiplier effects, which reflect not only in the creation of important added value but also in the capacity to drive, through a pull effect, the development of other economic activities (Silva \& Silva, 1998; Cabugueira, 2005). According to Botti et al. (2008), geographic proximity also plays an important role in the perceptions about the performance of tourism organisations, ensuring the survival of tourism companies and contributing or otherwise towards tourism sector competitiveness.

Tourist destination development has also received a great deal of attention in recent year not only as regards management field research but also in terms of tourism management (Enright \& Newton 2004; Shih, 2006; Schianetz, Kavanaghb \& Lockingtona, 2007; Zhang, Gu, Gu \& Zhang, 2011; Haugland, Ness, Gronseth \& Aarstad, 2011; Dwyer, Cvelbar, Edwards \& Mihalic, 2011). In fact, the interest in studying tourism management has attracted various different researchers. Many research projects report on concerns with the preservation of the surrounding environment and the social characteristics of the tourist destination: especially in coastal regions; the threat to protected species; the conservation of natural resources; the need for destination planning (Miller \& Auyong, 1991); the consequences of devastating disasters and the unpredictable nature of destiny (Faulkner \& Vikulov, 2001; Cioccio \& Michael, 2007); the long term conservation of wildlife resources (Wilson \& Tisdell, 2001; Ballantyne, Packer \& Hughes, 2009); the applicability of spatial ecology based tourism management techniques (Lusseau \& Higham, 2004); the tourist perceptions of protected marine reserves (Petrosillo, Zurlini, Corliano, Zaccarelli \& Dadamo, 2007) and the capacity to evaluate the quality of visitor experiences as well as protecting the natural environment (Tonge \& Moore, 2007). We would thereby reiterate the interest in identifying the state-of-the-art in tourism management. We furthermore question just which are the core themes to this field of knowledge developed by academics and published in high impact journals? What clusters might correspondingly get identified?

\section{Methodology, Data and Results}

\subsection{Methodology}

Bibliometric analysis refers to the application of quantitative and statistical analytical techniques to publications, such as articles and their respective citations and used to evaluate the performance of research. We would emphasise how this provides data on all the activities ongoing within a scientific field and an equally broad perspective on the impacts of research, especially on researchers, journals, countries and 
universities (Hawkins, 1977; Osareh, 1996; Thomsom Reuters, 2008).

Analysis of co-citations has proven a commonly deployed methodology for defining in detail the relationships ongoing within a specific scientific domain (Small, 1973) and assisting in defining the key scientific articles within the respective field (Zitt \& Bassecoulard, 1994). Two documents become cocited whenever cited jointly by one or more published articles (Smith, 1981); the number of joint citations enables the congregation of a representative proportion of the literature or field of knowledge and alongside identifying the influential authors and their respective interrelationships (White \& McCain, 1998). According to Verbeeck, Debackere, Luwel \& Zimmermann (2002), the existence of co-citations reveals that: (1) a citation implies usage; (2) a citation reflects excellence, meaning and impact; (3) citations are included to improve the research; (4) a cited document is related with the document citing it; (5) all citations are equal. In practice, various studies have already demonstrated the validity of cocitation analysis to grasp the intellectual structure of a particular research field (Di Guardo \& Harrigan, 2012).

This research project carried out an upstream analysis of article co-citations and a downstream analysis of the articles resulting from the former survey: firstly, analysis of the reference co-citations that fell within the scope of the main articles on tourism management before, subsequently, advancing with analysis of the co-citations of the articles researched based upon those citing them. This co-citation analysis of articles enabled the identification of a network of co-citations conveying the main articles on tourism management. This also enabled the grouping of articles through means of cluster analysis.

Additionally, this process involved analysis of the co-citations of authors and the journals quoted by articles on tourism management. This then defined the networks of authors and journals and proceeded with cluster analysis to define the groups resulting.

Analysis of the organisational affiliation of the lead authors, their geographic locations and their co-authors incorporated the number of works published with the collaboration ongoing between organisations analysed in conjunction with those of the co-authors while not attributing any weighting to the order in which the authors are listed in each article. For example, whenever an article is written by four different authors, belonging to four different organisations, we consider there are six co-author relationships. This thus identifies the combinations of organisations engaging in the most productive co-author relationships.

Finally, we analyse the number of publications per country and, in cases where authors belong to organisations in different countries, the level of international co-authorship. The results visually display the countries of authors as a cluster with co-author relationships as the links running between these clusters.
For all of these analytical procedures, we made recourse to VOSviewer software version 1.6.3, developed for the construction and visualisation of bibliometric maps. This software enables the combining of the VOS mapping technique with a strong visual component (Van Eck \& Waltman, 2009, 2010). The determining of the clusters and the respective networks of reference took place in accordance with the methodologies adopted by Waltman, Van Eck and Noyons (2010).

\subsection{Data}

We collected data from Science Citation Index Expanded (SClExpanded), Social Science Citation Index ( $\mathrm{SSCl}$ ) and Social Science Citation Index $(\mathrm{A} \& \mathrm{HCl})$, compiled by the online Thomson/Reuters-ISI database that contains thousands of academic publications and bibliographic information about the authors, their affiliations and the citations. The survey of the ISI Web of Science database spanned all articles published in journals classified as belonging to the management, business and economics categories without any chronological filter and applying the research terms "tourism management" and "management of tourism" to any part of the publication. The unit of analysis of this study is thus the publication with the variables gathered corresponding to the authors and their affiliations, the journal of publication, and the number of citations and references cited. This data collection procedure resulted in 402 articles with publication dates ranging from 1980 ( 1 article) and 2015 (50 articles).

\subsection{Results}

Our analysis of the results divides into four sections. Firstly, we set out our analysis of the journals (sources) that published the articles and the sources cited. Secondly, we develop the analysis in terms of the organisational affiliations of the authors and their respective cooperative networks of co-authors. In the third section, we deal with the national geographic location of authors alongside the transnational networks of co-authors. In the fourth and final section, we put forward a characterisation of the articles resulting from this research process, in particular the chronological evolution in the number of articles published in addition to identifying the most relevant articles and authors.

\subsubsection{Sources}

As regards the sources, the 402 articles returned by the research came from a total of 82 journals. Table 1 present the journals referenced in citations. The most cited journals are the following: Tourism Management (1930 citations), Annals of Tourism Research (303 citations), Journal of Sustainable Tourism (266 citations), Journal of Travel Research (163 citations) and Computers in Human Behavior (75 citations). As regards the number of articles published, the leading journals are Tourism Management (95 articles), Journal of Sustainable Tourism (28 articles), and Journal of Hospitality Leisure Sport \& Tourism Education (18 articles). 
Table 1 - Sources with at least 10 citations in the field of Tourism Management

\begin{tabular}{|c|c|c|c|}
\hline Journal & $\begin{array}{c}\text { Total } \\
\text { Citations }\end{array}$ & $\begin{array}{c}\text { Total } \\
\text { articles }\end{array}$ & $\begin{array}{c}\text { Mean citations by } \\
\text { article }\end{array}$ \\
\hline TOURISM MANAGEMENT & 1930 & 95 & 20.3 \\
\hline ANNALS OF TOURISM RESEARCH & 303 & 9 & 33.7 \\
\hline JOURNAL OF SUSTAINABLE TOURISM & 266 & 28 & 9.5 \\
\hline JOURNAL OF TRAVEL RESEARCH & 163 & 11 & 14.8 \\
\hline COMPUTERS IN HUMAN BEHAVIOR & 75 & 1 & 75.0 \\
\hline JOURNAL OF TRAVEL \& TOURISM MARKETING & 74 & 6 & 12.3 \\
\hline INTERNATIONAL JOURNAL OF CONTEMPORARY HOSPITALITY MANAGEMENT & 68 & 10 & 6.8 \\
\hline INTERNATIONAL JOURNAL OF HOSPITALITY MANAGEMENT & 63 & 11 & 5.7 \\
\hline LANDSCAPE AND URBAN PLANNING & 62 & 1 & 62.0 \\
\hline CURRENT ISSUES IN TOURISM & 59 & 12 & 4.9 \\
\hline MOUNTAIN RESEARCH AND DEVELOPMENT & 59 & 6 & 9.8 \\
\hline MARINE POLICY & 55 & 4 & 13.8 \\
\hline INTERNATIONAL JOURNAL OF TOURISM RESEARCH & 48 & 9 & 5.3 \\
\hline EXPERT SYSTEMS WITH APPLICATIONS & 45 & 4 & 11.3 \\
\hline JOURNAL OF HOSPITALITY LEISURE SPORT \& TOURISM EDUCATION & 39 & 18 & 2.2 \\
\hline JOURNAL OF CLEANER PRODUCTION & 32 & 2 & 16.0 \\
\hline JOURNAL OF ENVIRONMENTAL MANAGEMENT & 31 & 2 & 15.5 \\
\hline JOURNAL OF ORGANIZATIONAL CHANGE MANAGEMENT & 30 & 1 & 30.0 \\
\hline INTERNATIONAL JOURNAL OF ENVIRONMENTAL RESEARCH & 29 & 2 & 14.5 \\
\hline JOURNAL OF HOSPITALITY \& TOURISM RESEARCH & 29 & 3 & 9.7 \\
\hline INTERNATIONAL JOURNAL OF SERVICE INDUSTRY MANAGEMENT & 28 & 1 & 28.0 \\
\hline ENVIRONMENTAL MODELLING \& SOFTWARE & 26 & 1 & 26.0 \\
\hline BIOLOGICAL CONSERVATION & 24 & 2 & 12.0 \\
\hline SCANDINAVIAN JOURNAL OF HOSPITALITY AND TOURISM & 24 & 2 & 12.0 \\
\hline CONSERVATION BIOLOGY & 23 & 2 & 11.5 \\
\hline ENVIRONMENTAL MONITORING AND ASSESSMENT & 23 & 1 & 23.0 \\
\hline INTERNATIONAL JOURNAL OF PRIMATOLOGY & 21 & 1 & 21.0 \\
\hline ENVIRONMENTAL MANAGEMENT & 18 & 3 & 6.0 \\
\hline INTERNATIONAL JOURNAL OF MARKET RESEARCH & 18 & 1 & 18.0 \\
\hline ECOLOGICAL APPLICATIONS & 17 & 1 & 17.0 \\
\hline PLOS ONE & 15 & 1 & 15.0 \\
\hline BRITISH JOURNAL OF CRIMINOLOGY & 14 & 1 & 14.0 \\
\hline JOURNAL OF BUSINESS RESEARCH & 14 & 2 & 7.0 \\
\hline OECOLOGIA & 14 & 1 & 14.0 \\
\hline AFRICAN JOURNAL OF BUSINESS MANAGEMENT & 13 & 1 & 13.0 \\
\hline EUROPEAN JOURNAL OF MARKETING & 13 & 1 & 13.0 \\
\hline KNOWLEDGE-BASED SYSTEMS & 13 & 2 & 6.5 \\
\hline AQUATIC CONSERVATION-MARINE AND FRESHWATER ECOSYSTEMS & 12 & 1 & 12.0 \\
\hline GEOGRAFIE & 12 & 1 & 12.0 \\
\hline INTERNATIONAL JOURNAL OF GEOGRAPHICAL INFORMATION SCIENCE & 11 & 1 & 11.0 \\
\hline INTERNATIONAL JOURNAL OF MANPOWER & 11 & 1 & 11.0 \\
\hline ENVIRONMENTAL ENGINEERING AND MANAGEMENT JOURNAL & 10 & 3 & 3.3 \\
\hline SYSTEMS RESEARCH AND BEHAVIORAL SCIENCE & 10 & 1 & 10.0 \\
\hline
\end{tabular}

\subsubsection{Organisational Affiliation}

Analysis of the data relative to 454 organisations involved in the 402 articles published on the field of tourism management (Table 2) reveals that the organisations establishing the greatest presence are broadly either of Anglo-Saxon or Asian origin.

Table 2 - Leading Institutions for Publications on Tourism Management

\begin{tabular}{|l|c|c|}
\hline \multicolumn{1}{|c|}{ Organization } & No. of Articles & No. of Authors \\
\hline Hong Kong Polytechnic University (China) & 14 & 16 \\
\hline University of Queensland (Australia) & 11 & 16 \\
\hline Griffith University (Australia) & 8 & 12 \\
\hline University of Surrey (UK) & 7 & 8 \\
\hline Sejong University (South Korea) & 7 & 7 \\
\hline Florida State University System (USA) & 7 & 10 \\
\hline
\end{tabular}

Table 2 displays the pairs of organisations that present the greatest number of co-authored articles. Geographically, the strongest co-authorship relationship take place at organisations inside the United States with a lower incidence of international co-authorship. Nevertheless, we should reference the coauthors from the Simon Fraser University (Canada) and the
University of Cambridge (UK) with three joint articles; between the University of New Mexico (USA) and the University of Twente (Netherlands), and Imperial College London (UK) and Ghent University (Belgium), with both the latter cases returning two coauthored articles. Figure 1 features the network of co-authors in terms of organisations with at least four published articles. 
Figure 1 - Network of organisational collaboration (organisations with at least 4 articles)

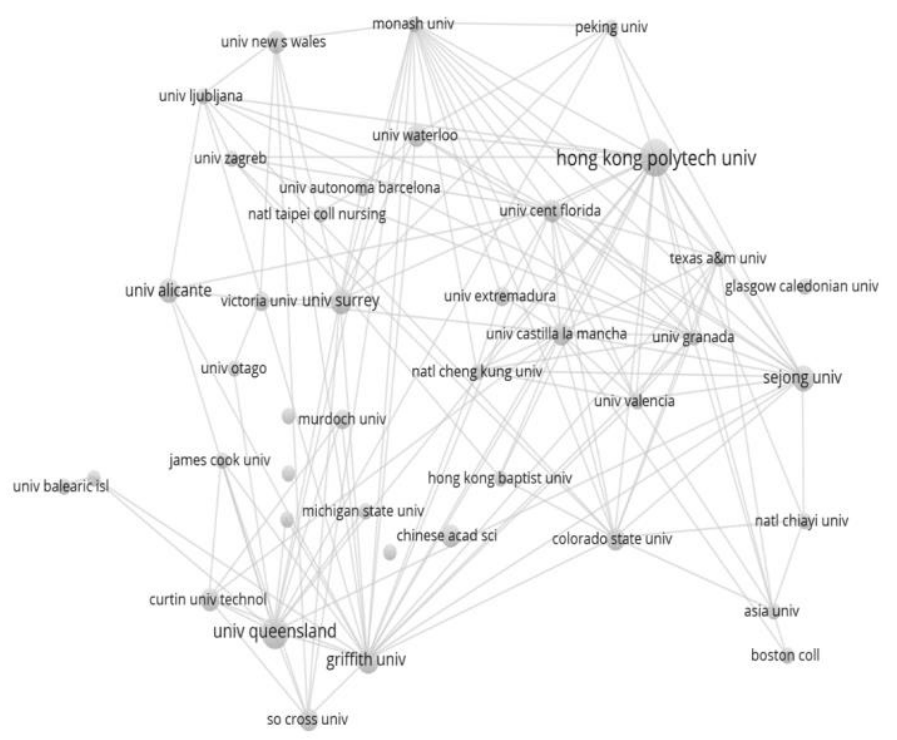

\subsubsection{Countries}

This analytical process identified authors for the 402 published articles from 64 different countries. Table 3 details those countries accounting for at least four articles in the field of tourism management. We would observe that the United States,
Australia and China are the countries with the greatest number of publications. The United States was the source of $17.2 \%$ of the articles returned by the database survey with Australia producing $15.7 \%$.

Table 3 - Leading countries for published tourism management articles

\begin{tabular}{|l|c|}
\hline Countries/Territories & No. of articles \\
\hline USA & 69 \\
\hline Australia & 63 \\
\hline People's R China & 49 \\
\hline Spain & 44 \\
\hline England & 41 \\
\hline Taiwan & 27 \\
\hline Canada & 19 \\
\hline New Zealand & 18 \\
\hline Italy & 16 \\
\hline Scotland & 13 \\
\hline South Africa & 11 \\
\hline South Korea & 10 \\
\hline Netherlands & 7 \\
\hline Greece & 7 \\
\hline Germany & 7 \\
\hline Turkey & 6 \\
\hline Japan & 6 \\
\hline Austria & 6 \\
\hline Slovenia & 5 \\
\hline Norway & 5 \\
\hline Iran & 5 \\
\hline France & 5 \\
\hline Switzerland & 4 \\
\hline Singapore & 4 \\
\hline Portugal & 4 \\
\hline Croatia & 4 \\
\hline Brazil & 4 \\
\hline & \\
\hline
\end{tabular}

Considering the co-authors coming from different countries, American authors published 12 articles in conjunction with authors from China, 6 articles with authors from Taiwan and 5 more from South Korea. The Australian authors published 5 articles with authors from China and 3 from New Zealand and the United Kingdom. Chinese authors, in addition to the already mentioned co-authors, also published 4 articles coauthored with academics from Taiwan. Figure 2 displays the network of co-authors from countries reporting at least 4 published articles. Visually, the organisations belonging to the same country get grouped into a single cluster with the size of each cluster proportional to the number of countries with which there are co-authored articles. The interconnections between the different countries indicate that there is at least one example of co-authorship between the respective countries. 
Figure 2 - Network of collaboration among countries (with at least 4 articles)

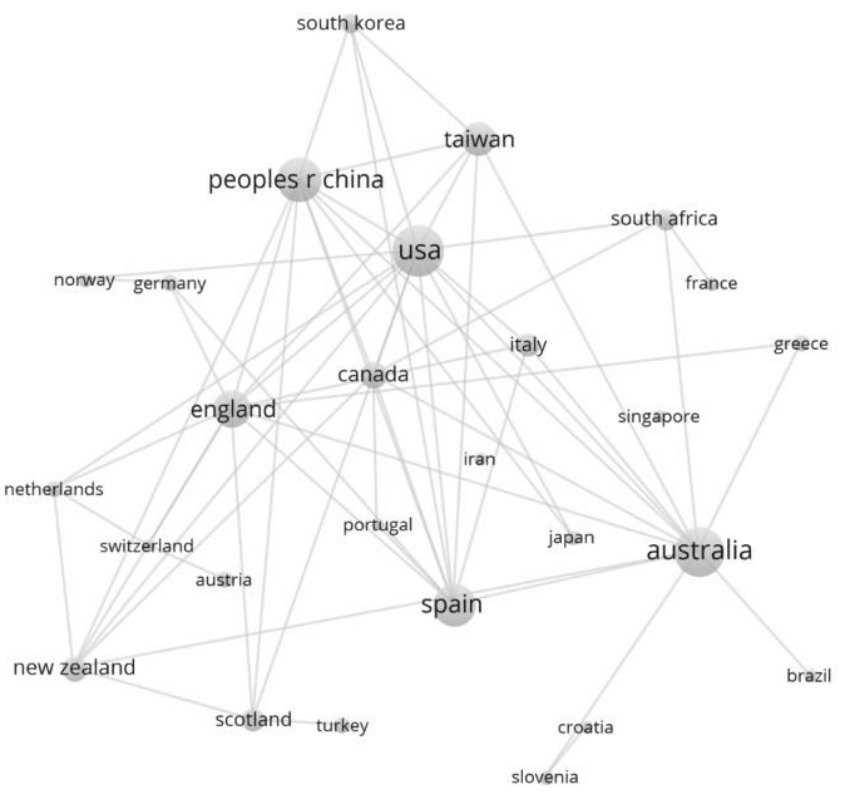

\subsubsection{Articles and Authors}

We analysed those articles returned by a search including the aforementioned keywords and resulting in a total of 402 articles. Figure 3 sets out the annual evolution in the number of published articles, with $2009.8 \pm 5.3$ the average year of publication and, in fact, portraying an emerging field of study. We correspondingly observe how the first published article dates to 1980 even though the second article only came a decade later (1990). Through to 2008, the number of articles published annually remains only rather modest in scope with that year seeing a sharp rise in the number of publications coming out on the field of tourism management. The years of 2013, 2014 and 2015 saw the peaks in the number of published articles, with 49,48 and 50 publications respectively.

\section{Figure 3 - Number of Articles by Year of Publication}

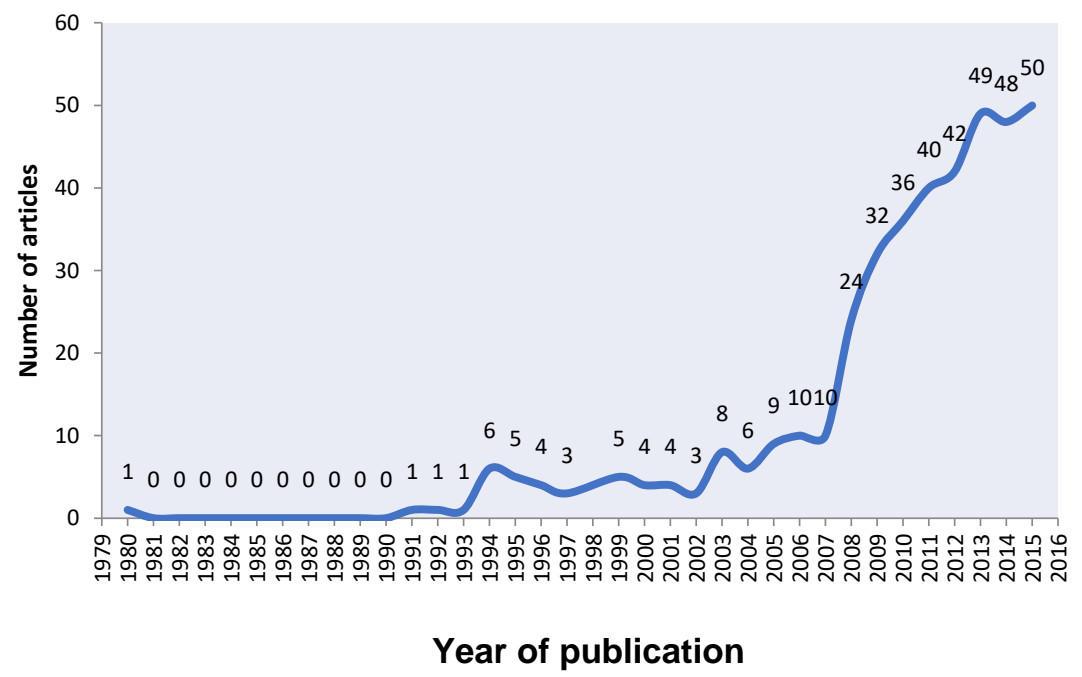

In terms of citations, the 402 articles report an average of $10.1 \pm$ 20.3 citations, 94 articles receive no citations and 144 articles were cited between one and five times. Table 4 lists those articles with the greatest number of citations identified by this research project. 
Estêvão, Garcia, Filipe \& Fernandes, Tourism \& Management Studies, 13(4), 2017, 30-42

Table 4 - Tourism Management articles with at least 30 citations

\begin{tabular}{|c|c|c|c|c|c|}
\hline & & $\begin{array}{c}\text { Total } \\
\text { Citations }\end{array}$ & & & $\begin{array}{c}\text { Total } \\
\text { Citations }\end{array}$ \\
\hline 1 & Litvin, Goldsmith, \& Pan (2008) & 241 & 17 & Lusseau \& Higham (2004) & 45 \\
\hline 2 & Xiang \& Gretzel (2010) & 213 & 18 & Miller \& Auyong (1991) & 45 \\
\hline 3 & Garrod \& Fyall (2000) & 80 & 19 & Telfer (2001) & 44 \\
\hline 4 & Ye, Law, Gu, \& Chen (2011) & 75 & 20 & Beaumont \& Dredge (2010) & 41 \\
\hline 5 & Kajanus, Kangas, \& Kurttila (2004) & 63 & 21 & Snaith \& Haley (1999) & 41 \\
\hline 6 & $\begin{array}{l}\text { Petrosillo, Zurlini, Corliano, Zaccarelli, \& Dadamo } \\
\text { (2007) }\end{array}$ & 62 & 22 & Bronner \& de Hoog (2011) & 40 \\
\hline 7 & Selin \& Chavez (1995) & 60 & 23 & $\begin{array}{l}\text { Jogaratnam, Chon, McCleary, Mena, \& Yoo } \\
\text { (2005) }\end{array}$ & 38 \\
\hline 8 & Hollinshead (1999) & 58 & 24 & van der Borg, Costa, \& Gotti (1996) & 37 \\
\hline 9 & Tonge \& Moore (2007) & 57 & 25 & Ashworth \& Page (2011) & 36 \\
\hline 10 & Hampton (2005) & 57 & 26 & Russo \& van der Borg (2002) & 35 \\
\hline 11 & Ballantyne, Packer, \& Hughes (2009) & 56 & 27 & Woodside, Cruickshank, \& Dehuang (2007) & 33 \\
\hline 12 & Faulkner \& Vikulov (2001) & 56 & 28 & Dolnicar \& Leisch (2008) & 32 \\
\hline 13 & Gomezelj \& Mihalic (2008) & 50 & 29 & Tribe (2008) & 31 \\
\hline 14 & Shaw, Bailey, \& Williams (2011) & 47 & 30 & Sainaghi (2006) & 31 \\
\hline 15 & Cioccio \& Michael (2007) & 46 & 31 & Xiao \& Smith (2006) & 30 \\
\hline 16 & Wilson \& Tisdell (2001) & 46 & 32 & Brown, Humphreys, \& Gurney (2005) & 30 \\
\hline
\end{tabular}

The three articles that receive the highest number of citations are, respectively:

1. Litvin, S. W., Goldsmith, R. E., \& Pan, B. (2008) Electronic word-of-mouth in hospitality and tourism management. Tourism Management, 29(3), 458-468 (241 Citations).

2. Xiao, H., \& Smith, S. L. J. (2006). Case studies in tourism research: A state-of-the-art analysis. Tourism Management, 27(5), 738-749 (213 Citations).
3. Garrod, B., \& Fyall, A. (2000). Managing heritage tourism. Annals of Tourism Research, 27(3), 682-708 (80 Citations).

We reduced the initial sample of 402 articles to those reporting at least thirty citations and resulting in 32 articles. This group was cited, in overall total terms, by 1,589 articles. Based on this set of articles, we then proceeded with analysis of the co-citations of these 32 articles. The sample then shrank to 31 articles with the removal of Brown et al. (2005) for containing no co-citations with its peers. The analysis of the co-citations served both to group the 31 articles in clusters (Table 5) and to set out the respective network of co-citations (Figure 4).

Table 5 - Clusters resulting from analysis of the co-citations in articles citing the $\mathbf{2 1}$ most cited articles

\begin{tabular}{|l|l|l|}
\hline \multicolumn{1}{|c|}{$\begin{array}{c}\text { Cluster 1 - Marketing and Tourism } \\
\text { Management }\end{array}$} & \multicolumn{1}{|c|}{$\begin{array}{c}\text { Cluster 2 - Tourism Management } \\
\text { Governance and Agendas }\end{array}$} & $\begin{array}{c}\text { Cluster 3 - Destination } \\
\text { Management and Sustainability }\end{array}$ \\
\hline Ashworth \& Page (2011) & Beaumont \& Dredge (2010) & Ballantyne et al. (2009) \\
\hline Bronner \& de Hoog (2011) & Cioccio \& Michael (2007) & Dolnicar \& Leisch (2008) \\
\hline Garrod \& Fyall (2000) & Faulkner \& Vikulov (2001) & Gomezelj \& Mihalic (2008) \\
\hline Hampton (2005) & Hollinshead (1999) & Lusseau \& Higham (2004) \\
\hline Kajanus et al. (2004) & Jogaratnam et al. (2005) & Petrosillo et al. (2007) \\
\hline Litvin et al. (2008) & Miller \& Auyong (1991) & Sainaghi (2006) \\
\hline Russo \& van der Borg (2002) & Selin \& Chavez (1995) & Tonge \& Moore (2007) \\
\hline Shaw et al. (2011) & Telfer (2001) & Wilson \& Tisdell (2001) \\
\hline Snaith \& Haley (1999) & Tribe (2008) & \\
\hline Van der Borg et al. (1996) & Xiao \& Smith (2006) & \\
\hline Woodside et al. (2007) & & \\
\hline Xiang \& Gretzel (2010) & & \\
\hline Ye et al. (2011) & & \\
\hline
\end{tabular}




\section{Figure 4-Network of co-citations and their respective clusters}

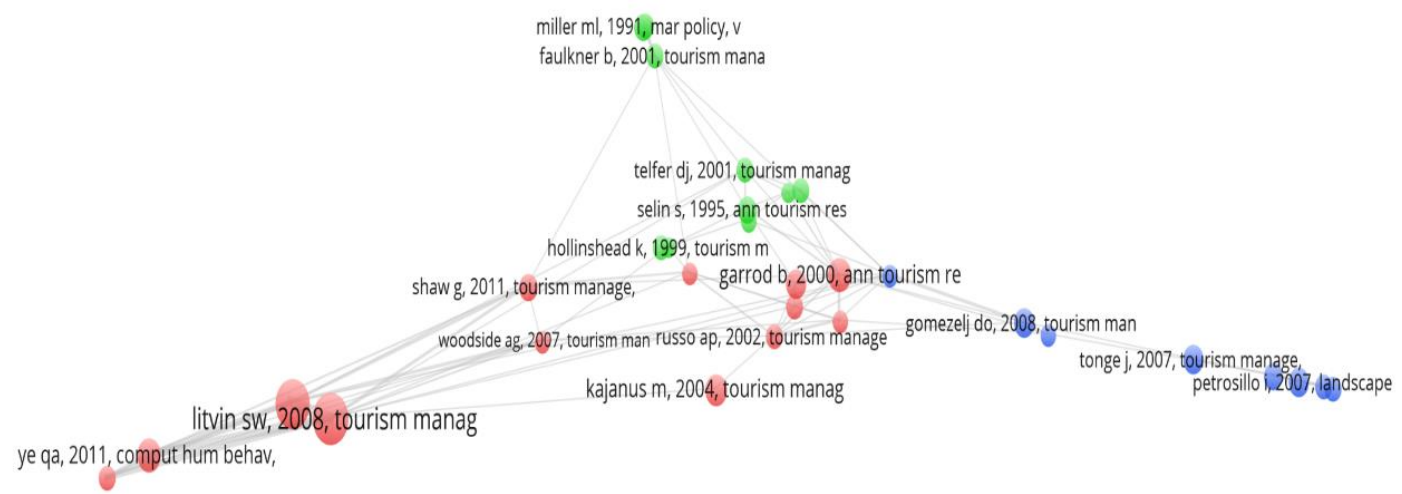

As regards the authors, and considering the aforementioned 402 articles, our results reveal that 959 authors were responsible for the total of publications. Table 6 displays the 50 most cited authors as well as the number of articles published and the citation average per article. This thus highlights the most cited authors: Goldsmith, Litvin and Pan, with 241 citations, Xiang, with 216 citations and Gretzel, with 213 citations. As regards the number of articles published, the results identify Law, with 5 articles and Kim, with 4 articles.

Table 6 - Most cited authors in tourism management

\begin{tabular}{|c|c|c|c|}
\hline Author & $\begin{array}{c}\text { Total } \\
\text { Citations }\end{array}$ & $\begin{array}{c}\text { Total } \\
\text { articles }\end{array}$ & $\begin{array}{c}\text { Mean citations } \\
\text { by article }\end{array}$ \\
\hline Goldsmith, RE & 241 & 1 & 241.0 \\
\hline Litvin, SW & 241 & 2 & 120.5 \\
\hline Pan, B & 241 & 1 & 241.0 \\
\hline Xiang, Z & 216 & 2 & 108.0 \\
\hline Gretzel, U & 213 & 1 & 213.0 \\
\hline Law, R & 127 & 5 & 25.4 \\
\hline Fyall, A & 80 & 1 & 80.0 \\
\hline Garrod, B & 80 & 1 & 80.0 \\
\hline Chen, W & 76 & 2 & 38.0 \\
\hline $\mathrm{Gu}, \mathrm{B}$ & 75 & 1 & 75.0 \\
\hline $\mathrm{Ye}, \mathrm{QA}$ & 75 & 1 & 75.0 \\
\hline Moore, SA & 74 & 2 & 37.0 \\
\hline van der Borg, J & 72 & 2 & 36.0 \\
\hline Faulkner, B & 70 & 2 & 35.0 \\
\hline Petrosillo, I & 67 & 2 & 33.5 \\
\hline Zurlini, G & 67 & 2 & 33.5 \\
\hline Dredge, D & 64 & 3 & 21.3 \\
\hline Kajanus, M & 63 & 1 & 63.0 \\
\hline Kangas, J & 63 & 1 & 63.0 \\
\hline Kurttila, M & 63 & 1 & 63.0 \\
\hline Corliano, ME & 62 & 1 & 62.0 \\
\hline Dadamo, M & 62 & 1 & 62.0 \\
\hline Zaccarelli, N & 62 & 1 & 62.0 \\
\hline Chavez, D & 60 & 1 & 60.0 \\
\hline Selin, S & 60 & 1 & 60.0 \\
\hline Bronner, $\mathrm{F}$ & 58 & 2 & 29.0 \\
\hline de Hoog, R & 58 & 2 & 29.0 \\
\hline Hollinshead, K & 58 & 1 & 58.0 \\
\hline Page, SJ & 58 & 2 & 29.0 \\
\hline Hampton, MP & 57 & 1 & 57.0 \\
\hline Higham, JES & 57 & 2 & 28.5 \\
\hline Tonge, J & 57 & 1 & 57.0 \\
\hline Ballantyne, $\mathrm{R}$ & 56 & 1 & 56.0 \\
\hline Hughes, $\mathrm{K}$ & 56 & 1 & 56.0 \\
\hline Packer, J & 56 & 1 & 56.0 \\
\hline Vikulov, S & 56 & 1 & 56.0 \\
\hline Woodside, AG & 51 & 3 & 17.0 \\
\hline Gomezelj, DO & 50 & 1 & 50.0 \\
\hline Mihalic, $T$ & 50 & 2 & 25.0 \\
\hline Nicolau, JL & 50 & 2 & 25.0 \\
\hline
\end{tabular}




\begin{tabular}{|l|l|l|l|}
\hline Nicolau, JL & 50 & 2 & 25.0 \\
\hline Shaw, G & 48 & 2 & 24.0 \\
\hline Bailey, A & 47 & 1 & 47.0 \\
\hline Dehuang, N & 47 & 2 & 23.5 \\
\hline Williams, A & 47 & 1 & 47.0 \\
\hline Cioccio, L & 46 & 1 & 46.0 \\
\hline Michael, EJ & 46 & 1 & 46.0 \\
\hline Tisdell, C & 46 & 1 & 46.0 \\
\hline Wilson, C & 46 & 1 & 46.0 \\
\hline Auyong, J & 45 & 1 & 45.0 \\
\hline Lusseau, D & 45 & 1 & 45.0 \\
\hline Miller, ML & 45 & 1 & 45.0 \\
\hline
\end{tabular}

\section{Discussion}

\subsection{Cluster 1 - Marketing and Tourism Management}

This cluster aggregates a set of studies that, in their majority, demonstrate the existence of a relationship between the fundamentals of marketing and tourism management. Thus, Ashworth \& Page (2011), in a reflection on the importance of developing the concept of urban tourism, warn about a need to adopt an approach that interconnects with the broader scope of the social sciences. They defend that the understanding of new concepts, such as urban tourism, will only deepen with research into tourism beginning to integrate the agendas of academic debates ongoing in the social sciences. Furthermore, Shaw, Bailey \& Williams (2011) approach the need to integrate tourism management into the broader debates taking place in the literature on management. They also introduce the concept of the dominant service logic as a paradigm for research into marketing management through a case study on the hotel industry in the United Kingdom.

Concerns over the development of tourism products and the prices at which they retail to the public constitute the focus of studies such as that by Garrod \& Fyall (2000). These authors investigated the main restrictions and imperatives for the long term management of built heritage attractions and highlighting three fundamental aspects: (i) the core mission of heritage attractions; (ii) the factors impacting on decisions regarding tourism ticket entrance price; and (iii) the perceptions of the heritage managers as regards the role of these attractions and the public agencies financing conservation, tourism and heritage management programs. The costs and benefits of the existence of attractions in close proximity also come in for analysis by Hampton (2005). This author approached the dynamics of the relationships among communities, historical sites and the tourism management structures, illustrating his research with the example of Borobudur, on Java, Indonesia.

Years earlier, Van der Borg, Costa \& Gotti (1996) considered the question of the costs outweighing the benefits before concluding that, in such contexts, tourism proves unsustainable and requiring intervention.

Woodside, Cruickshank \& Dehuang (2007) applied the statistical method proposed by Holt with the objective of drafting a strategy that enables the founding of tourism destinations as iconic brands.

Grasping the social impacts of tourism fundamentally requires knowing the opinion of residents. Snaith \& Haley (1999) sounded out the resident population about the impacts of tourism in a historical British city. The results conveyed distinctive effects across diverse and different socioeconomic and demographic indicators.

Russo \& Van der Borg (2002) tested out a visitor-friendliness framework of reference, a complex concept that integrates the main dimensions to the urban tourism product, such as quality, accessibility and the image projected. In accordance with information gathered from four European cities, they conclude that sometimes the most specific and smooth features matter to the attractiveness of a city to international visitors. The document furthermore identifies a series of "best practices" in tourism management.

The importance of local culture as a factor in tourism success, especially for rural tourism destinations, received the attention of Kajanus, Kangas \& Kurttila (2004), who defend that investing in local culture enables innovation and sustainable development.

Issues stemming from communication and public relations also attract the interest of researchers. Xiang \& Gretzel (2010) study to what extent media outlets appear as a result of search engines within the context of travel and tourism related searches. The analysis findings describe how the media provides a substantial proportion of the research results, indicating how these search engines guide potential travellers directly to online media sites. The study effectively confirms the rising importance of the media within the scope of online tourism. This furthermore demonstrates that the challenges faced by traditional suppliers of travel and tourism related information as well as the implications for online marketing strategies.

The importance of eWOM (electronic word of mouth) has also represented the focus of various studies. Bronner \& de Hoog (2011) observed how, during choice processes, the tourists, beyond reading and applying the information available over the Internet, also get involved with "posting" information. This phenomenon has generated other questions, such as around the type of tourist, their motivations for making the comments, the type of site visited and the respective characteristics of the message. They conclude that the reason for which tourists make comments influences their choice of site to contribute towards and the content of the contribution. Litvin, Goldsmith \& Pan (2008) described the importance of the interpersonal online and eWOM influence on the hotel and tourism industry and standing out as profitable channels for marketing by the sector. They additionally discussed some technological and ethical questions 
raised by marketing managers striving to leverage the emerging technologies and $e W O M$ as a means of tourism promotion.

Ye, Law, Gu \& Chen (2011) undertook a study to identify the impact of the comments posted by online users on business performance levels applying data extracted from a large online travel agency in China. The results show how traveller evaluations may have a significant impact on online sales with an increase of $10 \%$ in tourist numbers and over $5 \%$ in online reservations.

\subsection{Cluster 2 - Tourism Management Governance and Agendas}

The approaches made within the scope of this cluster span studies looking at the importance of planning, governance and sustainability for tourism destinations, public tourism policies, research agendas and the application of best practices.

Thus, Miller \& Auyong (1991) explained tourism as a complex process with enormous potential for altering both the environment and society. They refer to a renewed level of concern for marine focused polices alongside those for the habitat and protected threatened species, the conservation of resources and the quality of water, visits and tourism. The authors describe the sector under study as the largest in the world. They correspondingly detail the opportunities and problems inherent to the development of tourism in coastal zones. Furthermore, they call for the implementation of environmental and socioeconomic monitoring programs; the redefining of the tourism development models within the scope of contributing towards identifying acceptable limits to such changes; the design, implementation and strengthening of conservation areas (parks, sanctuaries, protected areas, biodiversity reserves); fostering the participation of the local community in the planning of appropriate tourism development foster sustainable tourism. With a case study methodology, they compared the efficiency of each network and its theoretical and practical contributions towards a better understanding of governance networks. The study found that each network interpreted the parameters of local tourism governance (positive cultures, constructive and community based communication; transparency and financing; vision and leadership; acceptance of diversity and striving for equity and inclusion; development of knowledge, learning and sharing specialised knowledge; well defined roles and responsibilities for participants alongside appropriate operational structures and processes) in different fashions and therefore highlighting the complex relationships between the parameters and the value systems. These tensions include (1) efficiency versus inclusion; (2) internal legitimacy versus external legitimacy and (3) flexibility versus stability. This highlights the potential for comparative research to adequately defining tourism policies.

Tribe (2008) also maintained that tourism should be a critical business and provided orientations in this direction. He defends that critical research is essential to constructing an agenda for the ethical management of tourism destinations and deems sustainability as fundamental to the long term survival of such destinations.

As regards individualised human actions, Faulkner \& Vikulov (2001) considered the evolutions that take place in tourism projects; establishing teaching and interpretation programs for ecotourism (public and private sectors) in their demand for the building of a citizenship for tourism.

Hollinshead (1999) analysed the ways in which the concept of the institutional/ professional gaze began to get incorporated into tourism studies. He therefore observes the way in which the gaze of power acts upon tourism institutions/ organisations/ travel and tourism agencies (and tourism and the research of trips and holidays). He details how this power of surveillance emerges through the normalisation of discourses and universal praxis clearly advocating certain understandings of heritage/ society/ the world through tourism. The article seeks to investigate the involvement of individuals in decision making over tourism based research and in the developing of tourism management practices in the expectation that different perspectives participate in the definition of the respective forms of governance. This interest interrelates with the need to understand whether researchers, across the various fields of tourism, participate in the drafting of policies targeting this sector of activity.

Already into the $21^{\text {st }}$ century, Telfer (2001) approached the strategic alliances formed along the extent of the Wine Route in Niagara. This studied how these contributed towards regional success as an enotourism destination whilst correspondingly stressing the importance of collaborative networks - involving wine producers and cellars, tourism operators, the restaurant industry - for regional development.

Later, Beaumonte \& Dredge (2008) investigated the ways in which different local tourism governance networks operated and the effects of this governance on initiatives designed to

destinations both when experiencing extreme natural events (flooding, cyclones, earthquakes) and damage caused by human actions (wars, pathological behaviours) and how destinations deal with the challenges inherent to such situations and the way in which such processes prove more efficient whenever a tourism disaster plan is already in effect.

Cioccio \& Michael (2007) analysed the ways in which the forest fires of 2003 afflicting the northeast of Victoria (Australia) and devastating over 1.1 million hectares, destroyed the means of subsistence of some operators and left over a thousand small tourism companies without any income stream. This study examined how they were prepared and to what extent they have recovered from the incident. They verified both the underlying vulnerability and lack of preparation to deal with a danger on such a magnitude. Furthermore, this demonstrated the resilience of operators as well as the trust in accumulated experience for managing the recovery process. They affirmed that various lessons might serve for application in similar future circumstances.

Similar to our research project, Jogaratnam, Chon, McCleary, Mena \& Yoo (2005) also returned results on the productivity of analysis on the the respective affiliations of authors, their respective reputations and the contributions made by the different regions of the world. 


\subsection{Cluster 3 - Destination Management and Sustainability}

The studies grouped into this cluster essentially approach the sustainability of tourism destinations and their environmental protection. For example, Wilson \& Tisdell (2001) verified how tourism, whenever well-managed, may contribute towards the long term conservation of wildlife resources, especially in cases when the species are already in decline due to the destruction of the natural habitats, hunting or human related threats (for example, sea-turtles).

Within this framework, Ballantyne et al. (2009) concentrated their focus on the development of wildlife based tourism attractions as a guarantee of the long term conservation of their fauna and habitats. The research results suggest that tourism management practices for wildlife tourism identify tourists as conservation partners and that the interactions established with wild animals are susceptible to satisfying the needs of both parties.

Dolnicar \& Leisch (2008) concluded that niche marketing represents a viable complement to the then currently prevailing sustainable tourism management techniques. This covers tourists who may not necessarily be interested in protecting the surrounding local environment. Tourism managers have also begun wielding an important role and, thus, Gomezelj \& Mihalic (2008) studied the way in which they influence the identification and exploration of the competitive advantages as well as analysing the competitive positionings of tourism destinations.

Lusseau \& Higham (2004) detailed a research program which used observational data to explore the applicability of spatial ecology tourism management techniques. The data presented scientifically proves the way in which determining a critical habitat through spatial-ecological analysis proved a powerful tool in the protection of marine mammals in New Zealand as well as in other locations. Other research findings in the field of tourism management approach the general problem of tourist perceptions of protected marine areas (PMA), focusing on the awareness of being in a PMA, on tourism management related activities, the importance of the components to the natural attractiveness for the satisfaction of tourists, experiences of leisure on the desires of tourists to return and their awareness over environmental impacts (Petrosillo et al., 2007).

According to Sainaghi (2006), destination management organisations play a critical role in assisting local companies as well as in the building of sustainable competitive advantages through choices regarding positioning.

The role of tourism visits was subject to analysis by Tonge \& Moore (2007) in their approach to the importance of boosting visitors to national and marine parks worldwide and concluding that effective management depends on the capacity to evaluate the quality of the experiences of visitors as well as the protection of the surrounding natural environment.

\section{Final Considerations}

This study sourced the ISI Web of Science database for the gathering of articles published in journals within the scope of the management, business and economic categories without any chronological filter. The research deployed the terms "tourism management" and "management of tourism" and reported wherever they were identified in the publication. This research survey returned 402 articles with publication dates ranging from 1980 ( 1 article) and 2015 (50 articles) and published by a total of 82 journals. The leading tourism management journals were: Tourism Management with 95 articles, followed by Journal of Sustainable Tourism, with 28 articles and Journal of Hospitality Leisure Sport \& Tourism Education, with 18 articles.

We furthermore identify the geographic distribution of the respective 959 authors across 64 countries and belonging to 454 organisations. The institutions with the largest weightings are of Anglo-Saxon and Asian origins. The USA, Australia and China prove the countries with the largest number of publications. The United States alone accounts for $17.2 \%$ of the articles identified by this research with Australia on $15.7 \%$. Furthermore, the United States also hosts the strongest co-authorship relationships.

Analysis of the annual trend in the numbers of published articles demonstrates that this remains an emerging field of research. Through to 2008 , there was only a fairly scant number of articles published annually. Furthermore, the years of 2013, 2014 and 2015 are those that represent the peaks in published articles.

Over the course of this study, the initial sample of 402 articles was reduced to articles registering at least thirty citations. This group was cited in 1,589 articles. We undertook analysis of these co-citations that underpinned the grouping of 31 article clusters.

In summary, this study systematises the main contributions emerging from the literature on tourism management. Through bibliometric analysis of the "tourism management" concept, we identify three major clusters within this research field of knowledge: Marketing and Tourism Management; Governance and Tourism Management Agendas; Destination Management and Sustainability.

The first cluster, Marketing and Tourism Management, reflects the research concerns surrounding the integration of the main principles of market orientation and marketing policies in the implementation, development and promotion of tourism. The second cluster, that we entitle Governance and Tourism Management Agendas, conveys the importance attributed by researchers to the planning, governance and sustainability of tourist destinations, public tourism policies and the research agendas alongside the application of best practices. The third cluster, Destination Management and Sustainability gathers research perceiving destination management as a contribution towards fostering competitive advantages, reflecting in the capacity of tourist destinations to apply their resources in an efficient and sustainable fashion over the medium and long term.

As the main limitations of this study, we may identify the fact that tourism represents a field in which various sciences hold interests and hence the nomenclature applied does not always prove the same. Various concepts get confused as is the case with tourism management and touristic management. In fact, as the object of research, tourism was initially studied by economists above all due to the growth in this sector of activity worldwide from the early $20^{\text {th }}$ century onwards. The management sciences, however, designed the first paradigms 
for this sector. The behavioural sciences- sociology, psychology, anthropology...- debate the influence that tourism holds over the social, political and cultural lives of the territories hosting such exchanges, forms of cooperation and conflict. Furthermore, geography developed studies and reflections on the benefits of tourism activities. A factor of territorial transformation, tourism nurtures contradictions and impacts across diverse spheres of power and the social subjects involved. The planning, the public policies, the means of existing management practices, the impacts caused and the role of the communities involved are other themes under debate and of priority to scientists from various fields of knowledge.

We would suggest future lines of research relate the nationalities of the most cited authors with the agendas ongoing in their respective countries as well as grasping whether the coauthored articles reflect national realities or global challenges. There would also be relevant findings from carrying out a more thorough analysis of the article keywords to better understand the fundamental contributions of these publications.

\section{References}

Alberti, F. \& Giusti, J. (2012). Cultural Heritage, Tourism and Regional Competitiveness: The Motor Valley Cluster. City, Culture and Society, 3, 261-273.

Alberton, A., Barddal, R. \& Campos, L. (2010). As dimensões e métodos de mensuração da sustentabilidade e o turismo: uma discussão teórica. Revista de Gestão Social e Ambiental, 4 (2), 138 -155.

Ashworth, G. \& Page, S. J. (2011). Urban tourism research: Recent progress and current paradoxes. Tourism Management, 32(1), 1-15.

Ballantyne, R., Packer, J., \& Hughes, K. (2009). Tourists' support for conservation messages and sustainable management practices in wildlife tourism experiences. Tourism Management, 30(5), 658-664.

Beaumont, N. \& Dredge, D. (2010). Local tourism governance: a comparison of three network approaches. Journal of Sustainable Tourism, 18(1), 7-28.

Botti, L., Camprubi, R. \& Torrès, O. (2008), Tourism and Regional Development: Small Businesses and Social Network for Competitivenes. Research Entrepreneurship and Small Business XXII, Universidad Beira Interior, Covilhã

Bronner, F., \& de Hoog, R. (2011). Vacationers and eWOM: Who Posts, and Why, Where, and What? Journal Of Travel Research, 50(1), 15-26.

Brown, A. D., Humphreys, M., \& Gurney, P. M. (2005). Narrative, identity and change: a case study of Laskarina Holidays. Journal Of Organizational Change Management, 18(4), 312-326.

Cabezas, A. (2008). Tourism and Social Exclusion in the Dominican Republic. Latin American Perspectives, The Impact of Tourism in Latin America. 35(3), 21 -36.

Cabugueira, A. (2005). "A Importância Económica do Turismo", Revista Turismo \& Desenvolvimento, Vol.II, №2, 97-104.

Campos, A., Mendes, J. \& Albino, J. (2006). Para uma Cultura da Qualidade Total no Destino Turístico: Métodos de Diagnostico e Estratégias de Desenvolvimento. Turismo \& Desenvolvimento, 5, 2140.

Carvalho, P. \& Vaz, M. (2005). A Estruturação do Problema na Definição de uma Estratégia de Desenvolvimento Turístico para a Serra da
Estrela - Portugal. VII Encontro Hispano-Luso de Economia Empresarial, Universidade do Algarve.

Cioccio, L., \& Michael, E. J. (2007). Hazard or disaster: Tourism management for the inevitable in Northeast Victoria. Tourism Management, 28(1), 1-11.

Crouch, G. (2007). Modeling Destination Competitiveness: A Survey and Analysis of the Impact of Competitiveness Attributes, National Library of Australia Cataloguing in Publication Data.

Crouch, G. I., \& Ritchie, J. R. B. (1999). Tourism, Competitiveness, and Societal Prosperity. Journal of Business Research, 44(3), 137-152.

Di Guardo, M. C., \& Harrigan, K. R. (2012). Mapping research on strategic alliances and innovation: a co-citation analysis. The Journal of Technology Transfer, 37, 789-811.

Dolnicar, S., \& Leisch, F. (2008). Selective marketing for environmentally sustainable tourism. Tourism Management, 29(4), 672-680.

Dwyer, L., Cvelbar, L., Edwards, D. \& Mihalic, D. (2011). Fashioning a Destination Tourism Future: The Case of Slovenia. Tourism Management, xxx, 1-12.

Enright, M. \& Newton, J. (2004). Tourism Destination Competitiveness: a Quantitative Approach. Tourism Management, 25, 777-778.

Faulkner, B., \& Vikulov, S. (2001). Katherine, washed out one day, back on track the next: a post-mortem of a tourism disaster. Tourism Management, 22(4), 331-344.

Garrod, B., \& Fyall, A. (2000). Managing heritage tourism. Annals of Tourism Research, 27(3), 682-708.

Gomezelj, D. O., \& Mihalic, T. (2008). Destination competitiveness Applying different models, the case of Slovenia. Tourism Management, 29(2), 294-307.

Haugland, S., Ness, H., Grønseth, B. \& Aarstad, J. (2011). Development of Tourism Destinations An Integrated Multilevel Perspective. Annals of Tourism Research, 38(1), 268-290.

Hawkins, D. T. (1977). Unconventional Uses of On-line Information Retrieval Systems: On-line Bibliometric Studies. Journal of the American Society for Information Science, 28(1), 13-18.

Hollinshead, K. (1999). Surveillance of the worlds of tourism: Foucault and the eye-of-power. Tourism Management, 20(1), 7-23.

Jackson, J. \& Murphy, P. (2002). Tourism Destinations as Clusters: Analytical Experiences From The New World. Tourism and Hospitality Research, 4(1), 36-52.

Jogaratnam, G., Chon, K., McCleary, K., Mena, M., \& Yoo, J. (2005). An analysis of institutional contributors to three major academic tourism journals: 1992-2001. Tourism Management, 26(5), 641648.

Kajanus, M., Kangas, J., \& Kurttila, M. (2004). The use of value focused thinking and the $A^{\prime}$ WOT hybrid method in tourism management. Tourism Management, 25(4), 499-506.

Lazzeretti, L., Boix, R. \& Capone, F. (2008). Do Creative Industries Cluster? Mapping Creative Local Production Systems in Italy and Spain. Industry and Innovation, 15(5), 549-567.

Litvin, S. W., Goldsmith, R. E., \& Pan, B. (2008). Electronic word-of-mouth in hospitality and tourism management. Tourism Management, 29(3), 458-468.

Lusseau, D., \& Higham, J. E. S. (2004). Managing the impacts of dolphinbased tourism through the definition of critical habitats: the case of 
bottlenose dolphins (Tursiops spp.) in Doubtful Sound, New Zealand. Tourism Management, 25(6), 657-667.

Miller, M. L., \& Auyong, J. (1991). Coastal Zone Tourism - A Potent Force Affecting Environment and Society. Marine Policy, 15(2), 75-99.

Mutschke, P., Mayr, P., Schaer, P., \& Sure, Y. (2011). Science models as value-added services for scholarly information systems. Scientometrics, 89(1), 349-364.

Osareh, F. (1996). Bibliometrics, Citation Analysis and Co-Citation Analysis: A Review of Literature I. Libri, 46(3), 149-158.

Petrosillo, I., Zurlini, G., Corliano, M. E., Zaccarelli, N., \& Dadamo, M. (2007). Tourist perception of recreational environment and management in a marine protected area. Landscape and Urban Planning, 79(1), 29-37.

Rodrigues, A. (2003). A Engenharia Turística como Factor de Desenvolvimento Regional: Alguns Conceitos e Aplicações. Nova Economia e Desenvolvimento Regional, Actas do IX Encontro Nacional da APDR, 1, 671-692.

Russo, A. P., \& van der Borg, J. (2002). Planning considerations for cultural tourism: a case study of four European cities. Tourism Management, 23(6), 631-637.

Sainaghi, R. (2006). From contents to processes: Versus a dynamic destination management model (DDMM). Tourism Management, 27(5), 1053-1063.

Schianetz, K., Kavanaghb, L. \& Lockingtona, D. (2007). The Learning Tourism Destination: The Potential of a Learning Organisation Approach for Improving the Sustainability of Tourism Destinations. Tourism Management, 28, 1485-1496.

Selin, S., \& Chavez, D. (1995). Developing an Evolutionary Tourism Partnership Model. Annals of Tourism Research, 22(4), 844-856.

Shaw, G., Bailey, A., \& Williams, A. (2011). Aspects of service-dominant logic and its implications for tourism management: Examples from the hotel industry. Tourism Management, 32(2), 207-214.

Shih, H. (2006). Network Characteristics of Drive Tourism Destinations: An Application of Network Analysis in Tourism. Tourism Management, 27, 1029-1039.

Small, H. (1973). Co-citation in the Scientific Literature : A New Measure of the Relationship Between Two Documents. Journal of the American Society for Information Science, 24, 265-269.

Smith, L. C. (1981). Citation analysis. Bibliometrics, Library Trends, 30(1) (Summer).

Snaith, T., \& Haley, A. (1999). Residents' opinions of tourism development in the historic city of York, England. Tourism Management, 20(5), 595-603. http://doi.org/10.1016/S02615177(99)00030-8

Silva, J. \& Silva, J. (1998). A Importância Económica do Turismo na Economia. Investigação em Turismo - Livro de Atas, 45-59.

Telfer, D. J. (2001). Strategic alliances along the Niagara Wine Route. Tourism Management, 22(1), 21-30.

Thomsom Reuters. (2008). Using bibliometrics: A guide to evaluating research performance with citation data (Retrieved). Retrieved from http://ipscience.thomsonreuters.com/m/pdfs/325133_thomson.pdf

Tonge, J., \& Moore, S. A. (2007). Importance-satisfaction analysis for marine-park hinterlands: A Western Australian case study. Tourism Management, 28(3), 768-776.
Tribe, J. (2008). Tourism: A Critical Business. Journal of Travel Research, $46(3), 245-255$

Van der Borg, J., Costa, P., \& Gotti, G. (1996). Tourism in European heritage cities. Annals of Tourism Research, 23(2), 306-321.

Van Eck, N. J., \& Waltman, L. (2009). VOSviewer : A Computer Program for Bibliometric Mapping - Erim Report Series Research in Management. Erim Report Series Research in Management.

Van Eck, N. J., \& Waltman, L. (2010). Software survey: VOSviewer, a computer program for bibliometric mapping. Scientometrics, 84(2), 523-538.

Verbeek, A., Debackere, K., Luwel, M., \& Zimmermann, E. (2002). Measuring progress and evolution in science and technology $-\mathrm{I}$ : The multiple uses of bibliometric indicators. International Journal of Management Reviews, 4(2), 179-211.

Waltman, L., van Eck, N. J., \& Noyons, E. C. M. (2010). A unified approach to mapping and clustering of bibliometric networks. Journal of Informetrics, 4(4), 629-635.

White, H. D., \& McCain, K. W. (1998). Visualizing a discipline: An author co-citation analysis of information science, 1972-1995. Journal of the American Society for Information Science, 49(4), 327-355.

Wilson, C., \& Tisdell, C. (2001). Sea turtles as a non-consumptive tourism resource especially in Australia. Tourism Management, 22(3), 279288.

Woodside, A. G., Cruickshank, B. F., \& Dehuang, N. (2007). Stories visitors tell about Italian cities as destination icons. Tourism Management, 28(1), 162-174.

Xiang, Z., \& Gretzel, U. (2010). Role of social media in online travel information search. Tourism Management, 31(2), 179-188.

Xiao, H., \& Smith, S. L. J. (2006). Case studies in tourism research: A stateof-the-art analysis. Tourism Management, 27(5), 738-749.

Ye, Q., Law, R., Gu, B., \& Chen, W. (2011). The influence of usergenerated content on traveler behavior: An empirical investigation on the effects of e-word-of-mouth to hotel online bookings. Computers In Human Behavior, 27(2), 634-639.

Zitt, M., \& Bassecoulard, E. (1994). Development of a method for detection and trend analysis of research fronts built by lexical or cocitation analysis. Scientometrics, 30, 333-351.

Zhang H., Gu, C., Gu, L. \& Zhang Y. (2011). The Evaluation of Tourism Destination Competitiveness by TOPSIS \& Information Entropy - A Case in the Yangtze River Delta of China, Tourism Management, 32, 443-451.

Received: 20 September 2016

Revisions required: 30 November 2016

Accepted: 15 February 2017 